\title{
PHOSPHORYLATION OF PROTEIN COMPONENTS OF ISOLATED ZYMOGEN GRANULE MEMBRANES FROM THE RAT PANCREAS
}

\author{
Monique LAMBERT, Jean CAMUS and Jean CHRISTOPHE \\ Department of Biochemistry, Brussels University School of Medicine, 1000 Brussels, Waterloo Boulevard 115, Belgium
}

Received 5 November 1974

\section{Introduction}

Our earlier results have already documented some aspects of protein phosphorylation in rat pancreas fragments [1]. The stimulation of amylase secretion by pancreozymin and caerulein was accompanied in vitro by an increase in ${ }^{32} \mathrm{P}$ orthophosphate incorporation into proteins, and especially so in the membrane proteins of zymogen granules. The mechanism involved in the activation by pancreozymin of protein kinase(s) directing these phosphorylations is not clearly established The role of cyclic AMP as an intracellular mediator is controversial [2-4] and recent evidence supports the participation of cyclic GMP [4]. The aim of the present investigation was to examine some properties of the isolated membranes of zymogen granules from the rat pancreas. We were able to detect an endogenous protein kinase activity capable of phosphorylating 8 to 10 membrane protein constituents as well as added histones. Cyclic AMP, and cyclic GMP to a lesser extent, exerted moderate stimulatory effects. These effects of cyclic nucleotides on membrane phosphorylation became more apparent upon addition of a partially purified soluble protein kinase also extracted from the rat pancreas.

\section{Materials and methods}

Zymogen granules were isolated from rat pancreas as described previously [1]. Secretory proteins were released in $0.2 \mathrm{M}$ bicarbonate at $\mathrm{pH} 8.2$. Membranes were purified by discontinuous gradient centrifugation according to Meldolesi [5]. They were utilized whitin the same day for the phosphorylation tests.
A crude protein kinase was also prepared. Rat pancreases were homogenized in $5 \mathrm{mM}$ phosphate buffer ( $\mathrm{pH} 7.0$ ) containing $4 \mathrm{mM}$ EDTA and $75 \mathrm{mM}$ $\epsilon$-aminocaproate. The homogenate was centrifuged at $27000 \times g$ for $30 \mathrm{~min}$. Ammonium sulfate was added to the supernatant to a final concentration of $30 \%$. The precipitate was collected, dissolved in $5 \mathrm{mM}$ phosphate ( $\mathrm{pH} 7.0), 2 \mathrm{mM}$ EDTA, $75 \mathrm{mM} \epsilon$-aminocaproate, and dialyzed overnight against the same buffer. This preparation was kept at $-90^{\circ} \mathrm{C}$.

The basal assay mixture for studying membrane phosphorylation contained, in a total volume of 0.2 $\mathrm{ml}, 200 \mu \mathrm{g}$ membrane proteins (as determined by the Folin assay), $10-20 \mu \mathrm{M}\left[\gamma^{3{ }^{3}} \mathrm{P}\right] \mathrm{ATP}$ (1 to $4 \cdot 10^{3}$ $\mathrm{cmp} / \mathrm{pmole}$; the Radiochemical Centre, Amersham, England), $50 \mathrm{mM}$ Tris- $\mathrm{HCl}$ ( $\mathrm{pH} 7.5), 1 \mathrm{mM}$ aminophylline, Trasylol (Bayer, Leverkussen, Germany) $500 \mathrm{UIK} / \mathrm{ml}$, and $10 \mathrm{mM} \mathrm{MgSO}_{4}$. When specified, the medium was supplemented with $10 \mathrm{mM} \mathrm{NaF}$, histones II A (Sigma, St. Louis, Missouri), $10^{-6} \mathrm{M}$ cyclic or $5 \cdot 10^{-6} \mathrm{M}$ cyclic GMP. The phosphorylation was initiated by the addition of radioactive ATP and conducted at $30^{\circ} \mathrm{C}$.

\section{Results and discussion}

Fig. 1 shows that phosphorylation proceeded rapidly, and that after $60 \mathrm{sec}$ a plateau was maintained for at least $5 \mathrm{~min}$. This reaction was not limited by the hydrolysis of $\left[\gamma \cdot{ }^{32} \mathrm{P}\right]$ ATP by membranous ATPase. Indeed, the addition of an ATP-regenerating system made of $7.5 \mathrm{mM}$ phosphoenolpyruvate and $25 \mathrm{U} / \mathrm{ml}$ pyruvate kinase did not improve the kinetics (data not shown). On the other hand, such a membrane preparation 


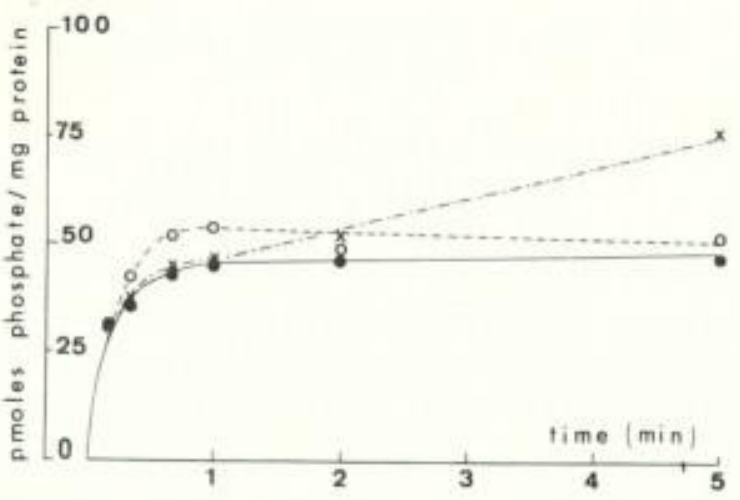

Fig. 1. Time-study of autophosphorylation of the membrane of zymogen granules with $\left[\gamma^{32} \mathrm{P}\right]$ ATP. This experiment was conducted as described under Materials and methods and is representative of 3 similar experiments. The phosphorylations were stopped by the addition of $10 \% \mathrm{CCl}_{3} \mathrm{COOH}$ and the pellets were filtered on Millipore AAWP (Bedford, U.S.A.). Results of one representative experiment $(\mathrm{n}=3)$ ). $(\bullet \bullet)$ basal medium; $(x-. x-. x) 10 \mathrm{mM} \mathrm{NaF} ;(\circ-\circ-0) 1 \cdot 10^{-6}$ M cyclic AMP.

had a moderate phosphoprotein phosphatase activity which was inhibited by $50 \%$ by $10 \mathrm{mM} \mathrm{NaF}$ (P.

Robberecht, personal communication). Fig. 1 illustrates that in the presence of $10 \mathrm{mM} \mathrm{NaF}$, protein phosphory. lation exceeded control values. The plateau appears therefore to result from an equilibrium between the opposite activities of protein kinase and phosphoprotein phosphatase in the zymogen granule membrane. $1 \cdot 10^{-6} \mathrm{M}$ cyclic AMP induced a moderate but consistent stimulation of autophosphorylation.
Table 1 shows a comparison of the endogenous activity of membranes with a preparation of soluble protein kinase(s) partially purified from the rat pancreas. The autophosphorylation of membranes was only slightly stimulated by $1 \cdot 10^{-6} \mathrm{M}$ cyclic AMP or $5 \cdot 10^{-6} \mathrm{M}$ cyclic GMP and the protein kinase activity exerted by these membranes on added histones II A was unaffected by cyclic nucleotides. On the other hand, the activity of soluble protein kinase(s) was markedly stimulated by $1 \cdot 10^{-6} \mathrm{M}$ cyclic AMP and $5 \cdot 10^{-6}$ M cyclic GMP. When this soluble preparation was added to membranes, the aggregate phosphorylation was lower than the sum of each autophosphorylation activities considered separately. The marked effect of cyclic nucleotides on this mixture suggests that the activity of soluble protein kinase(s) was predominating and contributed to the phosphorylation of membrane proteins. It can be hypothesized that a component of the crude soluble protein kinase preparation inhibited membrane protein kinase activity. It is more likely however that the affinity of semi-purified soluble protein kinase(s) for endogenous substrates was lower than that for membrane proteins. Competitive inhibition might render the autophosphorylation of soluble proteins negligible in the presence of zymogen granule membranes.

As shown in Table 2, extraction of membranes with $0.5 \mathrm{M} \mathrm{KCl}$ did not decrease the protein kinase activity measured on endogenous substrates or on added histones. In addition, this treatment did not affect the capacity of membranes to be phosphorylated in the

Table 1

Comparison of endogenous and exogenous protein kinase activities

\begin{tabular}{|c|c|c|c|c|c|}
\hline \multicolumn{3}{|c|}{ Proteins added } & \multicolumn{3}{|c|}{ pmoles phosphate $/ \mathrm{mg}$ protein. $10 \mathrm{~min}$} \\
\hline Zymogen & Soluble & Histones & no cyclic & cyclic & cyclic \\
\hline granule & protein & II A & nucleotide & AMP & GMP \\
\hline membrane & kinase & & added & & \\
\hline$(158 \mu \mathrm{g})$ & $(250 \mu \mathrm{g})$ & $(250 \mu \mathrm{g})$ & & $1-10^{-6} \mathrm{M}$ & $5-10^{-6} \mathrm{M}$ \\
\hline+ & 0 & 0 & 47 & 58 & 52 \\
\hline 0 & + & 0 & 21 & 33 & 26 \\
\hline+ & + & 0 & 27 & 59 & 44 \\
\hline+ & 0 & + & 125 & 125 & 116 \\
\hline 0 & + & + & 531 & 1004 & 811 \\
\hline
\end{tabular}

Assays were performed in the presence of $10 \mathrm{mM} \mathrm{NaF}$. Results of one representative experiment $(n=4)$. 
Table 2

Protein kinase activity of the membrane of zymogen granules after treatment with $0.5 \mathrm{M} \mathrm{KCl}$

\begin{tabular}{lll}
\hline Proteins added & \multicolumn{2}{l}{ pmoles phosphate/mg } \\
& protein. $5 \mathrm{~min}$ \\
\hline & $\begin{array}{l}\text { Control } \\
\text { membranes }\end{array}$ & $\begin{array}{l}\text { Washed } \\
\text { membranes }\end{array}$ \\
& & \\
\hline No addition & 48 & 73 \\
Soluble protein kinase ( $250 \mu \mathrm{g})$ & 110 & 129 \\
Histones II A $(250 \mu \mathrm{g})$ & 64 & 66 \\
\hline
\end{tabular}

Purified membrane pellets were suspended at $0^{\circ} \mathrm{C}$ in $50 \mathrm{mM}$ Tris- $\mathrm{HCl}(\mathrm{pH} 7.5)$ and Trasylol $500 \mathrm{UIK} / \mathrm{ml}$ in the presence or absence (control) of $0.5 \mathrm{M} \mathrm{KCl}$. These suspensions were recentrifuged for $10 \mathrm{~min}$ at $2500 \times \mathrm{g}$. The recovered membranes were then utilized for phosphorylation tests in the presence of $10 \mathrm{mM} \mathrm{NaF}$. Results of one respresentative experiment $(n=3)$. presence of exogenous protein kinase(s). Thus it appears that protein kinase activity and protein substrates for this enzyme were intrinsic parts of the zymogen membrane and can not be assimilated to exogenous proteins simply contaminating the membrane.

Individual protein components of the zymogen granule membrane were analyzed by polyacrylamide gel electrophoresis in sodium dodecylsulfate. Staining with Coomassie blue revealed at least 26 distinct bands (fig. 2A). The crude soluble protein kinase preparation when submitted to similar electrophoresis showed 10 to 12 bands, the main component having a mol.wt of 66000 (fig. 2B).

As can be seen in fig. 3,8 to 10 components of

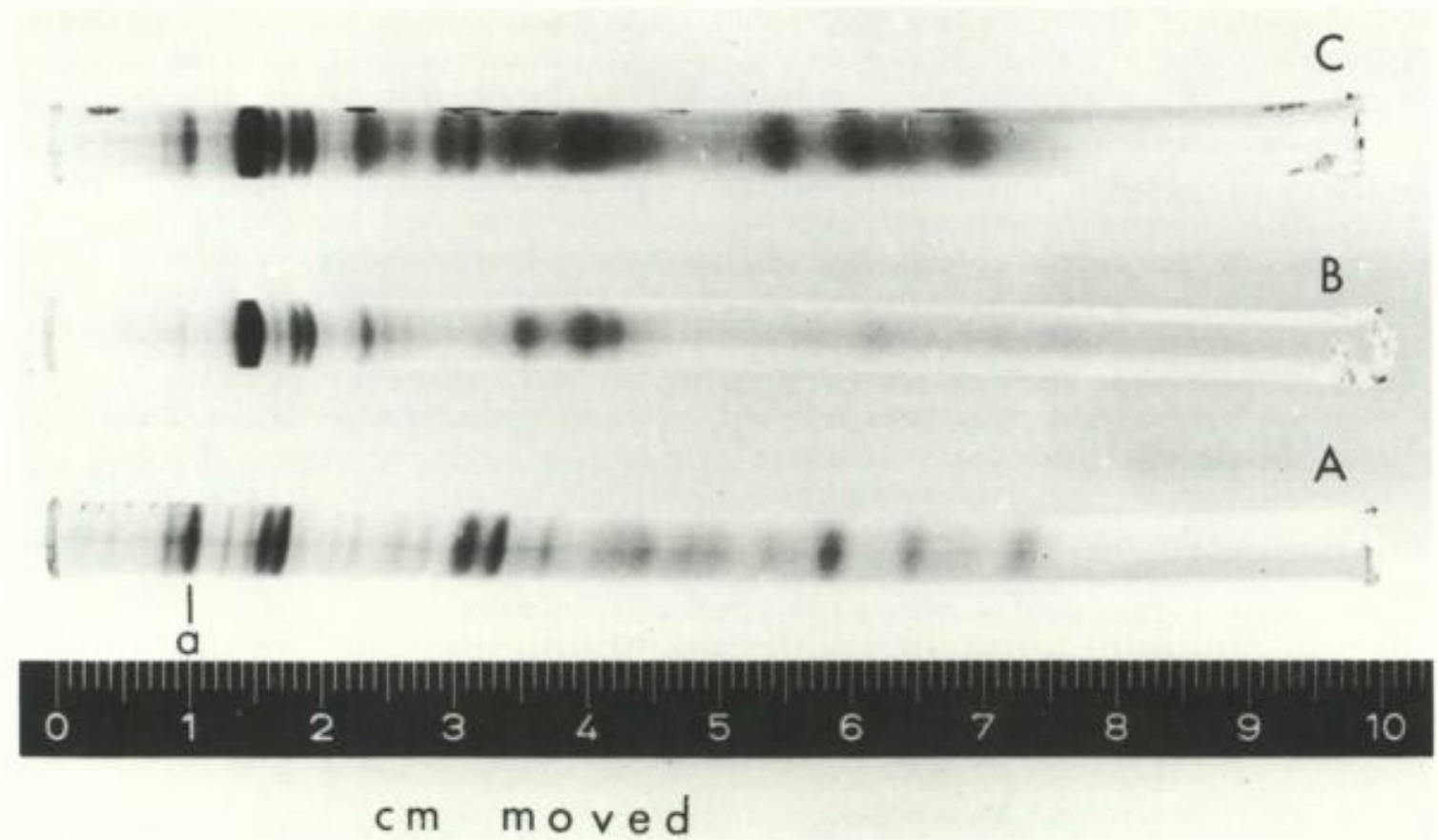

Fig. 2. Polyacrylamide gel electrophoresis in $0.1 \%$ sodium dodecylsulfate after 10 min incubation of: A: zymogen granule membrane from rat pancreas (a indicates the protein band most markedly phosphorylated in the high molecular weight range, as illustrated in fig. 3). B: semi-purified soluble protein kinase preparation from rat pancreas. C: a mixture of the two preceding extracts. The standard incubation medium described under Materials and methods was suplemented with $10 \mathrm{mM}$ NaF, Each incubation was stopped by the addition of $0.1 \mathrm{ml} 0.03 \mathrm{M}$ phosphate buffer $(\mathrm{pH} 7.2), 3 \%(\mathrm{v} / \mathrm{v}) \beta$-mercaptoethanol, $24 \%$ sucrose, $6 \%$ sodium dodecylsulfate. These samples were heated for $2 \mathrm{~min}$ at $100^{\circ} \mathrm{C} .25 \mu \mathrm{l}$ samples were then applied to polyacrylamide gels containing $10 \%$ acrylamide, $0.1 \%$ sodium dodecylsulfate, $0.1 \mathrm{M}$ sodium phosphate $(\mathrm{pH} 7.2), 0.125 \%$ persulfate, and $0.0135 \%$ Temed (from Fluka, Buchs, Switzerland). Electrophoresis was carried out for $270 \mathrm{~min}$ at $8 \mathrm{~mA} /$ tube. These gels were stained with Coomassie blue in $10 \%$ acetic acid-25\% isopropanol and destained in $10 \%$ acetic acid-10\% isopropanol. 


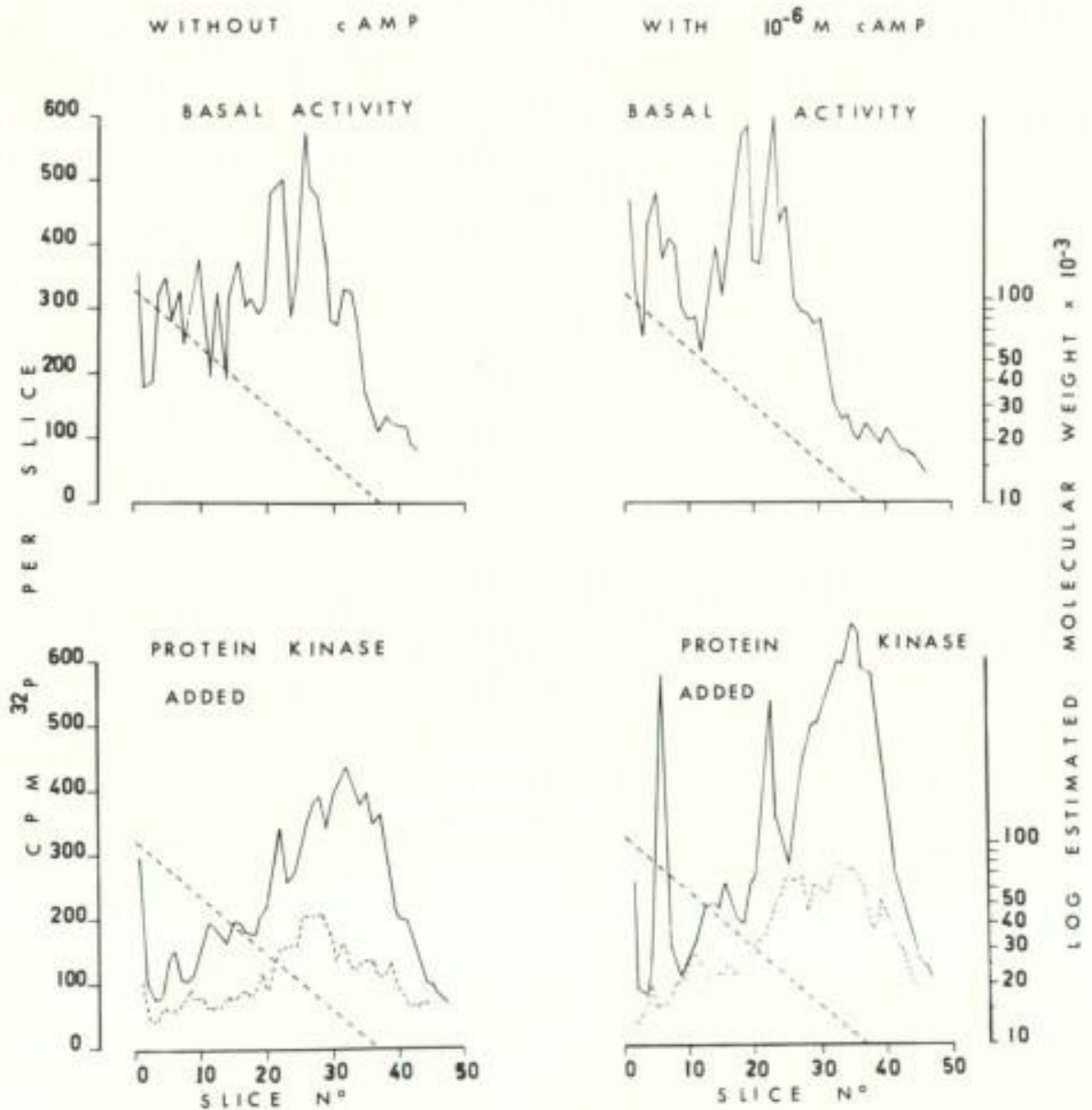

Fig. 3. Distribution of ${ }^{32} \mathrm{P}$ among the proteins of phosphorylated zymogen granule membranes, after separation by polyacrylamide gel electrophoresis in $0.1 \%$ sodium dodecylsulfate. After 10 min incubation carried out under the same general conditions as those in fig. 2 , in the presence of $10 \mathrm{mM} \mathrm{NaF}$ and with or without $1 \cdot 10^{-6} \mathrm{M}$ cyclic AMP, $100 \mu \mathrm{l}$ of SDS-solubilized proteins were applied to each gel. After electrophoresis, the gels were fixed overnight in $10 \%$ acetic acid-25\% isopropanol, washed in $10 \%$ acetic acid-10\% isopropanol and cut into $2 \mathrm{~mm}$ slices. The radioactivity was measured by scintillation counting. The autophosphorylation profile of the isolated crude soluble protein kinase preparation is illustrated by broken lines in the two lower panels. The linear relationship between molecular weight and the distance of migration was standardized with bovine serum albumin, hen ovalbumin, bovine carboxypeptidase $\mathrm{A}$, bovine ribonuclease and horse heart cy tochrome $c$.

the membrane with mol.wt ranging from 12000 to 70000 were phosphorylated by endogenous kinase. There was no specific effect of cyclic AMP on a particular protein species. These results are at variance with those reported by MacDonald and Ronzio [6] while our work was in progress. These authors noticed that more than $70 \%$ of ${ }^{32} \mathrm{P}$ was incorporated into a single protein of approximate mol.wt 130000 in zymogen granule membranes incubated for $5 \mathrm{sec}$ without aminophylline and $\mathrm{NaF}$ (this component was isolated by SDS polycrylamide gel electrophoresis at $\mathrm{pH} 2.4)$. After incubation in the presence of the exogenous kinase, we detected 8 phosphorylated components. Cyclic AMP increased the incorporation of $\gamma \cdot{ }^{32} \mathrm{P}$ in all molecular species but its effect was particularly pronounced for a protein with a mol.wt of approx. 70000 (Band a in fig. 2A).

In conclusion, it appears that 8 to 10 proteins in 
the zymogen granule membrane can be phosphorylated by an endogenous protein kinase. In addition, soluble protein kinase(s) can also phosphorylate the membrane of zymogen granules. The endogenous membrane protein kinase activity was only slightly dependent on cyclic nucleotides. If we assume that this kinase remained unaltered during membrane isolation, this observation might suggest that the in vivo phosphorylation of zymogen granule membrane is not under hormonal control. This conclusion would contradict our previous hypothesis, based on intact cell preparation [1], according to which phosphorylation of specific proteins could change granule membrane properties and facilitate the fusion with the plasma membrane during exocytosis. It is however possible to reconcile the data obtained on pancreas fragments and pancreas extracts if we admit that rises in the intracellular levels of cyclic GMP or cyclic AMP entail a dissociation of cytoplasmic protein kinase(s) and that the liberated catalytic subunit(s) are secondarily transferred on zymogen granule membranes, resulting in 'in situ' phosphorylation of 8 to 10 constituent proteins. This hypothesis finds some support in recent observations. Korenman et al. [7] demonstrated a translocation of cytoplasmic protein kinase towards microsomes, in a cyclic AMP-independent form, after stimulating rat uterus with isoproterenol. Our own preliminary results (unpublished data) indicate an important rise in membrane bound protein kinase activity when zymogen granule membranes of rat pancreas were incubated at $0^{\circ} \mathrm{C}$ in the presence of semi-purified soluble protein kinase and of $1.10^{-6} \mathrm{M}$ cyclic AMP.

\section{Acknowledgements}

This work was supported by Fonds de la Recherche Scientifique Médicale (Belgium), grant No. 20403. We wish to express our thanks to Dr Wald (Bayer, Brussels), for the gift of Trasylol and to Mrs Ballinckx and $\mathrm{Mr}$ Gelston for preparation of the manuscript.

\section{References}

[1] Lambert, M., Camus, J, and Christophe, J. (1973) Biochem. Biophys. Res. Commun. 52, 935-942.

[2] Case, R. M., Johnson, M., Scratcherd, T. and Sherratt, H. S. A. (1972) J. Physiol. 223, 669-684.

[3] Rutten, W. J., de Pont, J. J. H. H. M. and Bonting, S. L. (1972) Biochim. Biophys. Acta 274, 201-213.

[4] Robberecht, P., Deschodt-Lanckman, M., de Neef, P., Borgeat, P. and Christophe, J. (1974) FEBS Lett. 43. $139-143$.

[5] Meldolesi, J., Jamieson, J. D., Palade, G. E. and Evans, L. M. (1971) J. Cell. Biol. 49, 109-129.

[6] MacDonald, R. J. and Ronzio, R. A. (1974) FEBS Lett. 40, 203-206.

[7] Korenman, S. G., Bhalla, R. C., Sanborn, B. M. and Stevens, R. H. (1974) Science 183, 430-432. 